\title{
VARIATION OF PARAMETERS FOR DIFFERENTIAL EQUATIONS WITH CAUSAL MAPS
}

\author{
Z. DRICI, F. A. MCRAE AND J. VASUndHARA DEVI
}

Abstract. In this paper we obtain variation of parameters formula for differential equations with causal maps.

Mathematics subject classification (2000): 34D20.

Keywords and phrases: Causal operators, variation of parameters.

\section{REFERENCES}

[1] Corduneanu, C., Functional Equations with Causal Operators, Stability and Control: Theory, Methods and Applications, Taylor and Francis, London, 2002.

[2] Drici, Z., MCRAE, F. A., AND VAsundhara Devi, J., Set Differential Equations with Causal Operators, Mathematical Problems in Engineering, 2005, no. 2, 185-294.

[3] Drici, Z., MCRAe, F. A., AND Vasundhara DeVI, J., Set Differential Equations with Causal Operators in a Banach Space, Nonlinear Analysis TMA, Series A, 62 (2005), no. 2, 301-313.

[4] Drici, Z., McRae, F. A., AND Vasundhara Devi, J., Stability Results for Set Differential Equations with Causal Maps, Dynamic Systems and Applications, 15, (2006), no. 3-4, 451-463.

[5] DRICI, Z., MCRAE, F. A., AND VASUNDHARA DEVI, J., Monotone Iterative Technique for Periodic Boundary Value Problems with Causal Operators, Nonlinear Analysis TMA, 64 (2006), no. 6, 1153-1400.

[6] Lakshmikantham, V., LeEla S., Differential and Integral Inequalities, Volume I, Academic Press, New York 1969.

[7] Lakshmikantham, V., Rama Mohana RaO, M., Theory of Integro-Differential Equations, Gordon and Breach Science Publishers, Amsterdam, 1995. 